\title{
A Clinico-Pathological Study of Poly Morphous Light Eruption
}

\author{
Prasad Pullabatla ${ }^{1}$, Kaviarasan Pitchai Kaliyaperumal ${ }^{2}$, Udhay Sidhu ${ }^{3}$ \\ ${ }^{1}$ Rajah Muthiah Medical College \& Hospital, Annamalai University, Chidambaram, India; ${ }^{2}$ Department of Dermatology Venereology \& \\ Leprosy, Rajah Muthiah Medical College, Annamalai University, Chidambaram, India; ${ }^{3}$ Rajah Muthiah Medical College, Annamalai \\ University, Chidambaram, India. \\ Email: prasaderm@hotmail.com
}

Received January $22^{\text {nd }}, 2012$; revised February $26^{\text {th }}, 2012$; accepted March $10^{\text {th }}, 2012$

\begin{abstract}
The prevalence of PMLE varies from 5\% to $15 \%$ in various studies across the world. PMLE is noticed in the first three decades of life. The mean age in females is 33 years whereas in males it is 35 years. Females are more often affected than males. PMLE appears to be an immunologically mediated response possibly a delayed hypersensitivity phenomenon to a photo antigen induced or up regulated in the skin after sun exposure. One hundred new PMLE cases were included in a two year period from 2006-2008. All patients, who had been on treatment and with concomitant dermatoses were excluded. On histo-pathological examination $68 \%$ showed diagnostic features, $20 \%$ showed grade-II features and $12 \%$ grade-III features. Histo-pathological grading also varied with the duration of the disease. Early lesions showed only grade-II and III picture whereas the diagnostic picture was evident with the longer duration of the disease. In the plaque type, 14 cases showed characteristic histology after three to four months. In conclusion, PMLE is commonly observed in females between $21-30$ years of age. Pruritus is the chief complaint and the time required for the development of rash increases with time of sun exposure. Most common morphological type is papule on the forearm. Papules and plaque type of lesions of PMLE of longer duration clinched the histo-pathological diagnosis.
\end{abstract}

Keywords: Polymorphous Light Eruption; Histopathology

\section{Introduction}

In the year 1798 Robert Willian described an erythematovesicular eruption on sun exposed areas in the summer season due to the irritation of direct sunlight and named it as "eczema solare". This is the first description of polymorphous light eruption (PMLE). The term PMLE was introduced by Rasch in 1990 [1]. PMLE belongs to the idiopathic photo dermatoses together with actinic prurigo, hydroa vacciniforme, chronic actinic dermatitis and solar urticaria $[2,3]$. Some studies have claimed subsets of PMLE, like benign summer prurigo [4] and polymorphic light eruption sine eruptione [5]. Even today an unambiguous definition for PMLE does not exist [6].

The prevalence of PMLE varies from $5 \%$ to $15 \%$ in various studies across the world [7-10]. PMLE is noticed in the first three decades of life. The mean age in females is 33 years whereas in males it is 35 years [11]. Females are more often affected than males [12]. The etiology is not known and is likely to be multi factorial. It has a polygenic mode of inheritance $[13,14]$. The eruption of PMLE is induced by UVR and perhaps rarely by visible radiation, either by sunlight or by artificial sources in- cluding sun beds [15]. Holtze suggested that the action spectrum may vary for the different skin lesions. It may be due to UVB alone or to both UVA and UVB [1]. PMLE appears to be an immunologically mediated response possibly a delayed hypersensitivity phenomenon to a photo antigen induced or up regulated in the skin after sun exposure [16].

The morphology of skin lesions of PMLE varies [17]. Papular and vesicular types are very common. Other variants are plaque, erythema, odema, erythema multiforme and hemorrhagic types [18]. Period of sun exposure needed to trigger the eruption usually ranges from 30 minutes to several hours [19]. Lesions generally occur symmetrically and usually occur on exposed areas. In a cohort study it was observed that $24 \%$ of patients may have a spontaneous clearance [19].

The histologic features of PMLE are characteristic but not pathognomonic. The features vary according to the age of the lesion sampled. Very early lesion shows a mild spongiosis with focal lymphocytic exocytosis and an occasional mild to moderate superficial and deep perivascular, periadnexeal lympho histiocytic inflamma- 
tory infiltrate [20]. Lymphocytes are of CD4 type. The $\mathrm{T}$ cell infiltrate may be accompanied by endothelial changes [21]. Liquefactive degeneration may also be observed. Complement deposition has also been observed [22].

\section{Materials and Methods}

One hundred new PMLE cases were included in a twoyear period from 2006-2008. All patients, who had been on treatment and with concomitant dermatoses were excluded. Diagnosis was based on history and clinical findings. The diagnosis was independently confirmed by two senior dermatologists. Details of all patients in the study group were entered in a pre designed proforma. Base line investigations and skin biopsy were done. Histopathological examination was carried out by two pathologists to avoid an observer bias. Histo-pathological grading is given in Table $\mathbf{1}$.

\section{Results}

Out of 46,000 patients attended dermatology outpatient department, there were 230 cases, which accounted for $0.49 \%$ of the patient population. 100 cases were selected as per the criteria. The age and sex distribution is given in Figure 1.

There were $63 \%$ females and $37 \%$ males. $60 \%$ were manual laborers and 19\% were students. Pruritus was noticed in $54 \%$ of patients and in $17 \%$ there were no symptoms. Forty one percent had papules followed by plaques in $34 \%$. Seven percent had only macules, $5 \%$ had maculo papules, $10 \%$ had plaques and nodules and in $3 \%$ all types of lesions like macules, papules and plaques were observed. Minimum duration of the lesion was less than one month and the maximum eight months. In $26 \%$ of patient rash developed within one hour of sun exposure. This time interval was not known in $29 \%$ of cases. Associated symptoms were noticed in six patients. Four patients complained of headache and two patients fever and malaise. Face, nape of neck, back of neck, arm, forearm and lower limb were the sites of involvement. Fore- arm was the commonest site of lesions in $50 \%$ of cases. Lesions on the lower limb were also seen in $3 \%$ of patients.

On histo-pathological examination $68 \%$ showed diagnostic features, $20 \%$ showed grade-II features and $12 \%$ grade-III features. Histo-pathological grading compared with morphological lesion and duration of the disease is shown in Table 2.

\section{Discussion}

Prevalence of PMLE was found to be $0.49 \%$ in our study. Sharma et al. showed a prevalence rate of $0.56 \%$ from an Indian population [10]. The western population showed a higher prevalence $[7,8]$. PMLE is considered to be a disease of fair skinned individuals [23]. It is less common in India and Pakistan. The symptoms are also mild in our study patients. This also could explain the low prevalence in this study.

Male, female ration in this study was $1: 1.7$. Women were more frequently affected than men. This was consistent with earlier findings [11,24]. Female preponderance could be attributed to the recent demonstration of a female hormone 17- $\beta$ estradiol which prevents UVR induced suppression of the contact hypersensitivity response caused by the release of immuno suppressive cytokines (IL-10) from keratinocytes [12]. Women may also be more cognizant of their skin symptoms than men, which could result in an over-representation of women in clinical studies [25].

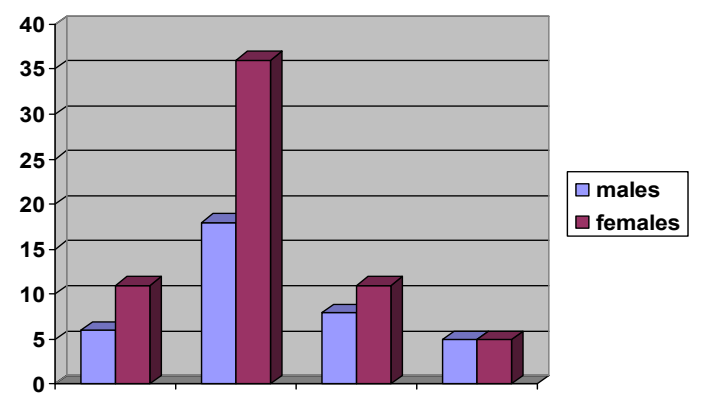

Figure 1. Age and sex distribution.

Table 1. Histo-pathological grading of PMLE.

\begin{tabular}{ll}
\hline Grade & Histo-pathological features \\
\hline \multirow{3}{*}{ I-Diagnostic } & $\begin{array}{l}\text { Epidermal changes: Hyperkeratosis/atrophy/spongiosis } \\
\text { Liquefactive degeneration may or may not be present } \\
\text { Dermis: Dense perivascular lymphocytic infiltrate in the upper and mid dermis }\end{array}$ \\
& Epidermis: Atrophy or spongiosis \\
II-Possible & De basal cell degeneration \\
& Epidermis: Nomphocytic infiltrate around the blood vessels but not dense changes \\
III-Probable & No basal cell degeneration \\
& Dermis: Minimal lymphocytic infiltrate around the blood vessels \\
\hline
\end{tabular}


Table 2. Histo-pathological grading vs. morphology of lesions and duration.

\begin{tabular}{|c|c|c|c|c|c|c|}
\hline Morphology & $<1$ month & $1-2$ & $3-4$ & $5-6$ & $7-8$ & Histo-pathological grading \\
\hline Macule & 3-grade-III & $\begin{array}{l}2 \text { grade-II } \\
1 \text { grade-III }\end{array}$ & 1 grade-III & - & - & $\begin{array}{l}\text { grade I-0 } \\
\text { grade II-3 } \\
\text { grade III-4 }\end{array}$ \\
\hline Papule & $\begin{array}{l}6 \text { grade-II } \\
2 \text { grade-III }\end{array}$ & $\begin{array}{l}8 \text { grade-I } \\
1 \text { grade-II }\end{array}$ & 12 grade-I & $\begin{array}{l}10 \text { grade-I } \\
1 \text { grade-II }\end{array}$ & 1 grade-I & $\begin{array}{l}\text { grade I-31 } \\
\text { grade II-8 } \\
\text { grade III-2 }\end{array}$ \\
\hline Plaque & - & $\begin{array}{l}1 \text { grade-I } \\
1 \text { grade-III }\end{array}$ & 14 grade-I & $\begin{array}{l}8 \text { grade-I } \\
2 \text { grade-II }\end{array}$ & 8 grade-I & $\begin{array}{l}\text { grade I-31 } \\
\text { grade II-2 } \\
\text { grade III-1 }\end{array}$ \\
\hline Macules \& papules & $\begin{array}{l}1 \text { grade-II } \\
2 \text { grade-III }\end{array}$ & 1 grade-II & - & 1 grade-II & - & $\begin{array}{l}\text { grade I-0 } \\
\text { grade II-3 } \\
\text { grade III-2 }\end{array}$ \\
\hline Papules \& plaques & 1 grade-III & $\begin{array}{l}1 \text { grade-I } \\
2 \text { grade-II }\end{array}$ & $\begin{array}{l}2 \text { grade-I } \\
1 \text { grade-II }\end{array}$ & 1 grade-I & 2 grade-I & $\begin{array}{l}\text { grade I-6 } \\
\text { grade II-3 } \\
\text { grade III-1 }\end{array}$ \\
\hline Macules, Papules \& plaques & - & 1 grade-III & - & 1 grade-II & 1 grade-III & $\begin{array}{l}\text { Grade I-0 } \\
\text { Grade II-1 } \\
\text { Grade III-2 }\end{array}$ \\
\hline
\end{tabular}

Majority of cases in our study were in the age group of 21 - 30 years which was consistent with earlier observations [12]. Mean age in females was 27.8 years whereas in males it was 30.5 years. Mastalier reported a mean age in men as 46 years and in women as 28 years [11]. Sixty percent were laborers which could be attributed to more sun exposure everyday when compared to other occupations. Pruritus was the most common symptom. This was also observed by Sharma et al. [10].

We found the time required to develop rash varied from less than 1 hour to 9 hours. This also increased with increasing working hours per day. This may be due to "hardening effect". The decline in severity of eruption or rash on repeated sun exposure or as summer progresses causes "hardening" [26]. Several authors have suggested that the hardening effect may be the result of increased pigmentation in the skin, epidermal thickening or immunological changes [19].

The mean duration $\mathrm{n}$ of the disease was 3.2 months (10 days - 8 months) in our study. Boonstra [24] and Mastalier [11] observed the mean duration as 9.2 and 6.5 years respectively. They included all cases of PMLE whereas we excluded patients on treatment and with other photo dermatosis, which could partly explain the shorter duration of the disease in our study population.

Several authors have speculated that PMLE is inherited as an autosomal dominant gene with reduced penetrance [27] but recent studies have shown a polygenic inheritance $[13,14]$. We recorded family history in $4 \%$ of patients. The heritability of PMLE varied between $6.25 \%$ $12 \%$ in various studies $[14,23]$.

As it is only a disease with minimal symptoms, many patients were not aware of similar symptoms in family members. In addition, the members of family work in different atmospheres and varying degree of sun exposure which could be responsible for the low familial incidence in our report. Constitutional symptoms were earlier reported by Indian studies [10].

Macules were seen as early lesion but the predominant lesions were papules $(41 \%)$ followed by plaques $(34 \%)$. This presentation was similar to other Indian studies [9, 10]. Boonstra [24] observed papules as the common presentation and Mastalier [11] observed papulo vesicular lesions.

Histo-pathology of PMLE was studied in all 100 cases. We defined our own criteria. Diagnostic histology was observed in $68 \%$, possible in $20 \%$ and probable in $12 \%$ of patients. Macules showed grade-II in $42.8 \%$ (3 cases) and grade-III in 57\% (4 cases). In this group, patients did not show diagnostic histopathology. Papules showed diagnostic histo-pathology in 31 of 41 patients $(75.6 \%)$ followed by grade-II in 8 cases and grade-III in 2 cases. Five cases in grade-I category showed a nodular collection of lymphocytes and histiocytes with claw like extension of epidermal rete ridges at the lateral boundaries of the lesion. Overlying epidermal atrophy, exocytosis and a superficial perivascular lymphocytic infiltrate was also observed. These cases resembled the histo-pathology of pin point variant of PMLE described by Bansal [27].

Out of 34 cases with plaque lesions grade-I histo-pathology was detected in $91.1 \%$ (31 cases). This was followed by grade-II in 2 cases and grade-III in 1 case. In the eighteen patients who presented with polymorphous eruption clinically, the results varied. Out of ten cases 
who presented with papules and plaques $60 \%$ showed characteristic histology. In the group comprising polymorphous eruptions including macules, there was no characteristic histology.

Histo-pathological grading also varied with the duration of the disease. Early lesions showed only grade-II and III picture whereas the diagnostic picture was evident with the longer duration of the disease. In the plaque type, 14 cases showed characteristic histology after three to four months.

In conclusion PMLE is commonly observed in females between 21 - 30 years of age. Pruritus is the chief complaint and the time required for the development of rash increases with time of sun exposure. Most common morphological type is papule on the forearm. Papules and plaque type of lesions of PMLE of longer duration clinched the histo-pathological diagnosis.

\section{REFERENCES}

[1] A. J. Stratigos, C. Antoniou and A. D. Katsambas, "Polymorphous Light Eruption," Journal of the European Academy of Dermatology and Venereology, Vol. 16, No. 3, 2002, pp. 193-206.

doi:10.1046/j.1468-3083.2002.00443.x

[2] T. P. Millard and J. L. Hawk, "Photosensivity Disorders: Cause, Effect and Management," American Journal of Clinical Dermatology, Vol. 3, No. 4, 2002, pp. 239-246. doi:10.2165/00128071-200203040-00002

[3] M. Lecha, "Idiopathic Photodermatoses: Clinical, Diagnostic and Therapeutic Aspects," Journal of the European Academy of Dermatology and Venereology, Vol. 15, No. 6, 2001, pp. 499-504. doi:10.1046/j.1468-3083.2001.00344.X

[4] M. Jeanmouqin and J. Civatte, "Benign Summer Light Eruption: A New Entity?" Archives of Dermatology, Vol. 122, No. 4, 1988, p. 376.

[5] J. S. Dover and J. L. Hawk, "Polymorphic Light Eruption Sine Eruption," British Journal of Dermatology, Vol. 118, No. 1, 1988, pp. 73-76. doi:10.1111/j.1365-2133.1988.tb01752.x

[6] E. Ledo, "Photodermatoses," Dermatologic Clinics, Vol. 12, 1994, pp. 797-803.

[7] W. L. Morison and R. S. Stern, "Polymorphic Light Eruption: A Common Reaction Uncommonly Recognized," Acta Dermato-Venereologica, Vol. 62, No. 3, 1982, pp. 237240.

[8] C. Pao, P. G. Norris, M. Corbett and J. L. Hawl, "Polymorphic Light Eruption: Prevalence in Australia and England," British Journal of Dermatology, Vol. 130, No. 1, 1994, pp. 62-64. doi:10.1111/j.1365-2133.1994.tb06884.x

[9] P. S. Murthy, P. K. Kar, S. Grover and R. Rajagopal, "Polymorphous Light Eruption in a Ground Crew," Indian Journal of Aerospace Medicine, Vol. 50, No. 1, 2006, pp. 39-43.

[10] L. Sharma and A. Basnet, "Clinico Epidemiological Study of Polymorphic Light Eruption," Indian Journal of Dermatology, Venereology and Leprology, Vol. 74, No. 1, 2008, pp. 597-602. doi:10.4103/0378-6323.38400

[11] U. Mastalier and H. Keri, "Clinical, Laboratory, PhotoTest and Phototherapy Findings in Polymorphic Light Eruption: A Retrospective Study of 133 Patients," European Journal of Dermatology, Vol. 8, No. 8, 1998, pp. 554559.

[12] F. Aubin, "Why Is Polymorphous Light Eruption so Common in Young Women?" Archives of Dermatological Research, Vol. 296, No. 5, 2004, pp. 240-241. doi:10.1007/s00403-004-0508-X

[13] J. M. McGregor, S. Grabezynska and R. Vaughan, "Genetic Modeling of Abnormal Photo Sensivity in Families with Polymorphic Light Eruption and Actinic Prurigo," Journal of Investigative Dermatology, Vol. 115, 2000, pp. 471-476. doi:10.1046/j.1523-1747.2000.00080.x

[14] T. P. Millard, V. Bataille and H. Snieder, "The Heritability of Polymorphic Light Eruption," Journal of Investigative Dermatology, Vol. 115, 2000, pp. 467-470. doi:10.1046/j.1523-1747.2000.00079.x

[15] J. K. Rivers, P. G. Norris and G. M. Murphy, "UV Sunbeds: Tanning, Photoprotection, Acute Adverse Effects and Immunological Changes," British Journal of Dermatology, Vol. 120, No. 6, 1989, pp. 767-777. doi:10.1111/j.1365-2133.1989.tb01374.x

[16] P. G. Norris, J. N. Barker and M. H. Allen, "Adhesion Molecule Expression in Polymorphous Light Eruption," Journal of Investigative Dermatology, Vol. 99, 1992, pp. 504-508. doi:10.1111/1523-1747.ep12616175

[17] A. K. Bajaj, "Polymorphic Light Eruption. What's New in Dermatology?" Vol. 33, 2002, pp. 2-12.

[18] E. Holzie, G. Plewig, C. Hofmann and E. Roser-Maass, "Polymorphous Light Eruption," Journal of the American Academy of Dermatology, Vol. 7, No. 1, 1982, pp. 111-125. doi:10.1016/S0190-9622(82)80018-2

[19] J. Ferugson and S. Ibbotson, "The Idiopathic Photodermatoses," Seminars in Cutaneous Medicine and Surgery, Vol. 18, No. 4, 1999, pp. 257-273. doi:10.1016/S1085-5629(99)80025-X

[20] J. H. Epstein, "Polymorphous Light Eruption," Journal of the American Academy of Dermatology, Vol. 3, No. 4, 1980, pp. 329-343. doi:10.1016/S0190-9622(80)80324-0

[21] P. G. Norris, J. Morris, D. M. McGibbon, C. Chu, J. L. Hawk, "Polymorphic Light Eruption: An Immuno Pathological Study of Evolving Lesions," British Journal of Dermatology, Vol. 120, No. 2, 1989, pp. 173-183. doi:10.1111/j.1365-2133.1989.tb07781.x

[22] J. E. Muhibauer, M. C. Mihm and J. J. Harrist Jr., "Papular Polymorphic Light Eruption: Fibrin, Complement and Immunoglobulin Detection," Archives of Dermatology, Vol. 120, No. 7, 1984, pp. 866-868. doi:10.1001/archderm.1984.01650430052009

[23] A. M. Ros and G. Wennersten, "Current Aspects of Polymorphous Light Eruption in Sweeden," Photodermatology, Vol. 3, No. 5, 1986, pp. 298-302.

[24] H. E. Boonstra, H. Von Weelden, J. Toonstra and W. A. Van Vloten, "Polymorphous Light Eruption: A Clinical, 
Photobiologic and Follow-Up Study of 110 Patients," Journal of the American Academy of Dermatology, Vol. 42, No. 2, 2000, pp. 199-207. doi:10.1016/S0190-9622(00)90126-9

[25] M. Berg, "Epidemiological Studies of the Influence of Sun Light on the Skin," Photo-dermatology, Vol. 6, No. 2, 1989, pp. 80-85.

[26] C. T. Jansen, "The Natural History of Polymorphous Light Eruption," Archives of Dermatology, Vol. 115, No.
2, 1979, pp. 165-169.

doi:10.1001/archderm.1979.04010020011004

[27] I. Bansal, H. Kerr, J. J. Janiga and M. S. Quershi, "Pinpoint Papular Variant of Polymorphous Light Eruption: Clinical and Pathological Correlation," Journal of the European Academy of Dermatology and Venereology, Vol. 20, No. 4, 2006, pp. 406-411. doi:10.1111/j.1468-3083.2006.01482.x 